\title{
Yeni Koronavirüs Salgını Dolayısıyla Gündeme Gelen Sosyal İzolasyon ve Gönüllü Karantina Döneminde İnternet ve Sosyal Medya Kullanımı*
}

\author{
Internet and Social Media Use in the Period of Social Isolation and Voluntary Quarantine which \\ comes to the Agenda Due to the New Coronavirus Outbreak
}

Ozan Yıldırım, Dr. Öğr. Üyesi, Niğde Ömer Halisdemir Üniversitesi İletişim Fakültesi, E-posta: ozanyildirim@ohu.edu.tr İdil İpek, 100/2000 Doktora Öğrencisi, Anadolu Üniversitesi Sosyal Bilimler Enstitüsü, E-posta: ipekkidil@gmail.com

https://doi.org/10.47998/ikad.788255

Anahtar Kelimeler: $\quad$ Öz

Koronavirüs, Covid- 19, İnternet, Sosyal Medya.
Web 2.0 teknolojisi, bireysel yayıncılığa olanak sağlaması, etkileşim ve içerik yaratma gibi özellikleri mümkün kılmasıyla internet kullanımında dönüm noktası olmuştur. Ayrıca, gündelik yaşamda internet ve sosyal medya kullanımının ön plana çıkmasına katkı sağlamıştır. Öte yandan, internet ve sosyal medya kullanımına ilişkin gerçekleştirilen çalışmalar olumlu ve olumsuz olmak üzere iki kutuplu şekilde değerlendirilmektedir. $\mathrm{Bu}$ çalışmada, internet ve sosyal medya kullanımı ile ilgili bütünsel bir değerlendirme yapılmış, yeni tip koronavirüs salgını dolayısıyla sosyal izolasyon ve gönüllü karantina uygulayan kişilerin internet ve sosyal medya kullanım alışkanlıklarının değerlendirilmesi amaçlanmıştır. Tematik analiz yönteminin temel alındığı çalışmada, 6 kadın ve 6 erkekle çevrimiçi yarı yapılandırılmış görüşmeler gerçekleştirilmiştir. Elde edilen veriler, salgın döneminde değişen internet ve sosyal medya kullanım alışkanlıkları, sosyal izolasyon ve gönüllü karantina döneminde internet ve sosyal medya kullanım amaçları, sosyal izolasyon ve gönüllü karantina döneminde internet ve sosyal medyanın kazandırdıkları ve salgın döneminde dijital içerik takibi ve üretimi olmak üzere dört kategoride çözümlenmiştir. Pandemi sürecinde internet ve sosyal medya kullanım oranlarında artış olduğu belirlenmiştir. $\mathrm{Bu}$ durumun olumlu ve olumsuz sonuçları olduğu tespit edilmiştir. Olumlu açıdan bilgiye erişim, iletişim, gündem takibi, sanal kültürel faaliyetler ve uzaktan eğitim gibi durumlar ön plana çıkarken, olumsuz açıdan boş zamanın tamamının internet ve sosyal medyada geçirilmesi, eğlence içeriklerinin daha fazla ilgi çekmesi gibi noktalara işaret edilmiştir.
Keywords:

Coronavirus,

Covid-19,

Internet,

Social Media.

\section{Abstract}

Web 2.0 technology has become a turning point in internet usage by enabling individual publishing, interaction and contente creation. In addition, it contributed to the prominence of internet and social media usage in daily life. On the other hand, studies on internet and social media use are considered as positive and negative. In this study, a holistic evaluation of internet and social media use was made, and it was aimed to evaluate the internet and social media usage habits of people who put themselves into social isolation and voluntary quarantine due to the new type of coronavirüs epidemic. In the study which is based on the Thematic analysis method, online semi-structured interviews were conducted with 6 women and 6 men. The data obtained were analyzed in four categories: changing internet and social media usage habits during the epidemic period, internet and social media usage purposes during social isolation and quarantine period, social isolation and social media during the period of social isolation and digital contente monitoring and production during the epidemic period. It was determined that there was an increase in the rate of internet and social media usage during the pandemic. It has been determined that this situation has positive and negative consequences. On the positive side, situations such as Access to information, communication, following the agenda, virtual cultural activities and distance education came to the fore, while negative aspects such as spending all of the free time on the internet and social media and entertainment contente becoming more attractive.

\footnotetext{
*: Bu çalışmanın uygulama kısmı, 2-7 Nisan 2020 Tarihleri arasında gerçekleştirilmiştir. Bu çalışmanın uygulama kısmı, 10 Nisan 2020 tarihinde 31 büyükşehir ve Zonguldak için alınan sokağa çıkma yasağı öncesinde gerçekleştirildiği için çalışmada "gönüllü karantina" kavramı kullanılmıştır.
}

Araştırmacı Orcid ID : : 1:https://orcid.org/0000-0001-7737-6311, 2: 0000-0002-9490-3774

Geliş Tarihi : : 31.08 .2020

Kabul Tarihi $\quad: 23.12 .2020$ 


\section{Giriş}

İnternet ve sosyal medya kullanımı gündelik yaşamın vazgeçilmez unsurlarından biridir. Son y1llarda dünyada ve Türkiye'de internet, sosyal medya ve akıllı telefon kullanım oranlarında artış olmuştur. Özellikle, web 2.0 teknolojisinin gelişimi ve internet kullanıcılarına sağladığı avantajlar sayesinde bu kullanım oranları gün geçtikçe artmaktadir.

Bilgiye erişim, gündemi takip etme, etkileşim, içerik üretme, bankacılık, alışveriş vb. gündelik yaşam aktivitelerini kolaylıkla gerçekleştirebilme, sosyalleşme, yayın yapabilme gibi avantajları barındıran internet ve sosyal medya, enformasyon toplumunun gerekliliği haline gelmiştir.

İnternet ve sosyal medya kullanımı ile ilgili yapılan çalışmalar genel anlamda iki kutuplu şekilde ortaya çıkmaktadır. Teknolojik belirlemecilik yaklaşımı çervesinde, internet ve sosyal medya kullanımının sadece olumlu özelliklerini gören yaklaşımlar; demokrasi, etkileşim, bireysel yayıncılığın yükselişi ve katılımcı kültür bağlamında bu teknolojileri olumlamaktadır. Bu düşüncelere karşıt olarak, internet ve sosyal medyayı geleneksel medya üretim pratikleriyle aynı şekilde değerlendiren yaklaşımlar ise, nefret söylemi, dezenformasyon, sayısal eşitsizlik değerlendirmeleriyle bu teknolojileri eleştirmektedir. $\mathrm{Bu}$ çalışmada ise dünyanın ve Türkiye'nin yaşadığı olağanüstü bir dönemde internet ve sosyal medya kullanımı hem olumlu hem de olumsuz özellikleriyle bütünsel olarak değerlendirilmiştir.

2019 yılının son günlerinde Çin'in Wuhan kentinde ortaya çıkan yeni tip koronavirüs (Covid-19) kısa süre içerisinde dünyanın geneline yayılmış ve pek çok ölüme sebep olmuştur. Dünya Sağlık Örgütü koronavirüsü pandemi eşdeyişle dünyanın geneline yayılan ve oldukça tehlikeli olan bir hastalık olarak kabul etmiştir (Medyaspoe. tv, 2020). Hastalık Türkiye'de 11 Mart 2020 tarihinde görülen ilk vakanın Sağlık Bakanı Dr. Fahrettin Koca tarafından açıklanmasıyla vatandaşlarımız için farklı bir boyut kazanıştır (TRTHaber.com, 2020). Türkiye devleti bu süreçte hastalığın yayılmaması için pek çok önlem almıştır (Onedio.com, 2020). 65 yaş üstü ve 20 yaş altı için sokağa çıkma yasağı ilan edilen Türkiye'de diğer yaş aralığında kalan vatandaşlar için özellikle gönüllü karantina ve sosyal izolasyon olguları gündeme gelmiştir.

Koronavirüs hastalığının yayılmasını engellemek için uygulanabilecek en etkili yöntemler sosyal izolasyon ve bireylerin kendilerini karantina altına almasıdır. Bu dönem içerisinde "evdehayatvar" sloganı pek çok kamu kuruluşu, özel sektör, televizyon kanalı ve internet kullanıcısı tarafından kullanılmış ve bireylerin evde kalması tavsiye edilmiştir. Bu dönemde Türkiye'deki internet servis sağlayıcılarının yaptığı açıklamaya (Habertürk. com, 2020) göre özellikle 15 Mart'tan itibaren gündüz saatlerinde internet kullanımı yüzde 50 oranında artmıştır.

$\mathrm{Bu}$ çalışmanın amacı, farklı meslek gruplarına mensup ve sosyal izolasyon ile gönüllü karantinayı uygulayabilen kişilerin, salgın döneminde sosyal medya ve internet kullanım alışkanlıklarının ne yönde olduğunu araştırmaktır. Bu bağlamda 6 kadın 6 erkekle internet üzerinden yarı yapılandırılmış derinlemesine görüşmeler yapılmış ve araştırmanın 
amacına uygun olarak şu tematik kategoriler oluşturulmuştur: 1. Salgın Döneminde Değişen İnternet ve Sosyal Medya Kullanım Alışkanlıkları, 2. Sosyal İzolasyon ve Gönüllü Karantina Döneminde İnternet ve Sosyal Medya Kullanım Amaçları, 3. Sosyal İzolasyon ve Gönüllü Karantina Döneminde İnternet ve Sosyal Medyanın Önemi-Kazandırdıkları ve 4. Salgın Döneminde Dijital İçerik Takibi ve Üretimi. Oluşturulan kategoriler tematik analiz yöntemi ile çözümlenmiştir.

Tematik analiz, bir veri kümesi içerisindeki kalıpları veya temaları tanımlamak, analiz etmek ve raporlamak için kullanılan nitel bir yöntem (Braun ve Clarke, 2006: 79) olup, "kodlama ve tema geliştirme üzerine odaklanmış analitik bir işlem" şeklinde tanımlanabilir (Lyons ve Rohleder, 2014: 96). Tematik analiz, araştırma konusunun daha derin ve geniş bir şekilde anlaşılmasına katkıda bulunur (Marks ve Yardley, 2004). Nitel çalışmada amaç derinlikli sonuçlar elde etmektir. Bu çalışmada da katılımcıların sosyal izolasyon ve gönüllü karantina sürecinde gündelik yaşamlarında internet ve sosyal medyanın nasıl yer kapladığı derinlikli olarak incelenmiştir.

Tema, bir veri biriminin neyle ilgili olduğunu ve ne anlama geldiğini tanımlayan bir ifade ya da cümledir (Saldana, 2009: 139). Temalar; s1k kullanılan kelimeler, yinelenen faaliyetler, anlamlar ya da duygulara dair ifadeler gibi kalıplardan türetilir (Taylor ve Bogdan, 1989: 131). Tematik analiz, öncelikle temaların belirlenmesi ve analizin bu temalara göre yapılması (Fereday \& Muir-Cochrane, 2006) ya da öncelikle temel kategorilerin belirlenerek buna bağlı olarak temaların belirlenmesi (Simons, Lathlean, \& Squire, 2008) şeklinde uygulanabilmektedir. Bu çalışmada da gönüllü karantina, sosyal izolasyon ve internet, sosyal medya en temel kelimelerdir ve temalar bu kelimeler üzerinden oluşturulmuştur.

Çalışmada her bir katılımcıya eşit şartlar sunulmuş, kendilerini ifade etme noktasında herhangi bir süre sınırlaması getirilmemiştir. Yarı yapılandırılmış derinlemesine görüşme tekniğinin doğasına uygun olarak, katılımcılara önceden belirlenmiş sorulara ek olarak verdikleri yanıtlar doğrultusunda ek sorular da yöneltilmiştir.

\section{İnternet ve Sosyal Medya Kullanımı}

Bilgisayarın ve internetin temelleri 1970'li yıllarda atılmakla birlikte 1990'ların ikinci yarısından itibaren internet ticarileşmiş ve yaygınlık kazanmıştır (Tokgöz, 2015: 395). Öte yandan, internet ve internet kullanımının itici güçlerinden birini oluşturan sosyal medya gündelik yaşantımızda oldukça önemli bir yer kaplamaktır. İnternet teknolojisinin başlangıcı web 1.0 ile olmuştur. Daha sonra, web 2.0 teknolojisi ile internet alanında kayda değer gelişmeler gerçekleşmiştir. Web 2.0 teknolojisine atfedilen önemin temel nedenlerinden biri sosyal ağların oluşumuna sağladığı katkıdır. Son yıllarda ise web 3.0 teknolojisi tartışılmaktadır (Yıldırım, 2019: 34).

Sosyal medyanın gelişimi ve toplumsal yaşamda yoğun bir şekilde kullanılır hale gelmesi internet alanında yaşanan gelişmeler sayesinde olmuştur. Sosyal ağ ya da sosyal paylaşım sitesi: "kullanıcıların kendileri ile ilgili kişisel haberleri verebileceği, arkadaş edinebileceği veya arkadaşları ile etkileşimli bir şekilde iletişim kurabileceği, resimlerini, 
videolarını paylaşabilecekleri, çeşitli etkinlikler düzenleyebilecekleri” (Eldeniz, 2010: 26- 27) mecralar olarak tanımlanmaktadır. Bu paylaşım ağlarına örnek olarak başlangıçta elektronik posta iletişimi (e-posta), Messenger, GTalk gibi uygulamalar aracılığıyla sanal iletişim ortamı oluşturulmuştur. Daha sonraki dönemlerde ise Facebook, Twitter, Instagram, YouTube, Swarm gibi uygulamalar üzerinden iletişim kurmak ve biraraya gelmek mümkün olmuştur (Güngör, 2018: 398).

Bu sanal platformlar, kişilerin farklı profillerde kullanıcılarla biraraya gelmelerine ve ortak ilgileri doğrultusunda paylaşımlarda bulunmalarına olanak sağlayan alanlara işaret etmektedir. Eşdeyişle, sosyal medya araçları kişilerin; bilgi edinmek ve paylaşımlarda bulunmak, etrafta olup bitenlerden haberdar olmak ve yalnızlıklarını gidermek için kullandıkları mecralardır.

Yeni sanal ortamlar, geleneksel medyadan farklı birtakım özellikler içermektedir. $\mathrm{Bu}$ yeni araçların bazı özellikleri; "etkileşimcilik, anındalık, izleyici yerine kullanıcı, üretim ve tüketimin giriftliği, merkezsizlik, iç içe geçişli sanal gerçeklik, iç içe geçişli kamusal alanlar, özel alan, kamusal alan giriftliği, ekonomik oluşu, hiyerarşik ilişkilerin önemsenmemesi” (Güngör, 2018: 398- 400) olarak s1ralanabilir.

Etkileşim özelliği sosyal medya araçlarını, geleneksel medyadan ayıran temel özelliklerden biri olarak ön plana çıkmaktadır. Etkileşim özelliği internet kullanıcısını pasif konumdan çıkararak, ara yüzeydeki farklı kullanıcılarla iletişime geçmesine ve paylaşımlarda bulunmasına olanak sağlamaktadır. Kaldı ki, bir toplumsal paylaşım ağında gerçekleşen üretime birçok farklı kullanıcı yorum ekleyerek katkıda bulunulabilmektedir (Binark ve Bayraktutan, 2013: 19-20).

İnternete olumlu açıdan yaklaşan araştırmacıların buluştukları ortak noktalar; geleneksel medyanın tek taraflı, etkileşime olanak tanımayan yapısına karşın; internetin katılımcı kültüre olanak sağladığı ve bilginin dağıtımı noktasında tüm topluma erişim hakkı tanıdığ 1 yönündedir. Eşdeyişle, internetin erişim sağlayabilen herkese eşit ve güvenli katılım olanağı tanıdığı ileri sürülmektedir (Çakır, 2015: 19). Teknolojik belirlenimci olan bu yaklaşım, teknolojik araçlara tamamen olumlu anlamlar yüklemektedir. İktidar yapılarını, sosyal ve ekonomik eşitsizlik gibi konuları göz ardı ederek; teknolojik araçların gölgesinde eşit bir gelecek vadetmektedir.

İnternete olumlamacı açıdan yaklaşanların işaret ettiği bir diğer nokta ise internetin zaman ve mekan gibi sınırlılıkları ortadan kaldırması, denetimden uzak bir yapıya sahip olması, bilginin üreticisi konumundaki bireyi ön plana ç1karması ve sıralanan tüm bu özellikleri bağlamında özgürleştirici bir etkiye sahip olmasıdır (Çakır, 2015: 23). Bir başka deyişle, internet, geleneksel medyanın sınırlayıcı ve tepeden tabana yayılım yönündeki bilgi akışını tersine çeviren bir karaktere sahiptir.

Teknoloji ve dolayısıyla internete olumlu anlamlar yükleyen araştırmacıların başında Kanadalı iletişim uzmanı Marshall McLuhan gelmektedir. Araç iletidir diyen ve iletişim aracının ilettiği mesajın değil biçiminin önemli olduğunu vurgulayan McLuhan'a göre, elektrik ve elektronik devrim sayesinde bugün tüm dünyanın birbirinden haberdar olduğu bir topluluk haline geldiği bir küresel köyde yaşamaktayız (Baldini, 2000: 88; Özçetin, 2018: 247). Günümüzde ise küresel köy kavramı internet ve sosyal medya 
sayesinde karşılık bulmaktadır. İnternet ve sosyal medyanın yapısal özelliklerden ötürü herkes, her an, her yerdedir ve adeta küçük bir köyde yaşarmış gibi insanlar birbirinden haberdar olabilmektedir.

McLuhan küresel köy kavramsallaştırması ile elektronik medyanın insanlığı yeniden birleştirdiğini, eşitliği sağladığını ve zaman ve mekan olgularını ortadan kaldırarak tek bir bilinçlilik haline dönüştürdüğünü vurgulamaktadır. Kaldı ki, elektrik, medyanın nitelikleri üzerinde de etkili olmuştur. Medyaya hız ve süreklilik gibi özellikler kazandıran elektrik, elektronik çağda bilginin herkesçe ulaşılabilir bir biçime dönüşmesini sağlamıştır (Altay, 2005: 17; Bourse ve Yücel, 2012: 108).

Medyanın toplumlar üzerinde oldukça güçlü bir etkiye sahip olduğunun altını çizen McLuhan, bir araç olarak medyanın alımlayanların algısını biçimlendirdiğini önemle vurgulamaktadır. $\mathrm{Bu}$ doğrultuda televizyona büyük önem atfeden McLuhan, araca gereken önemin verilmemesi durumumda yeni teknolojilerin insanlar üzerinde nasıl bir etkiye sahip olduğunun anlaşılmasının güçlügüune dikkat çekmektedir (Altay, 2005: 15- 16). Tüm bu ifadelerden McLuhan'in teknolojik araçlara olumlu anlamlar yüklediği anlaşılmaktadır. Öte yandan, günümüz kapitalist toplum yapısında tüm bu söylemlerin oldukça iyimser ifadeler olarak kaldığını belirtmek yanlış olmayacaktır.

İnternete olumlu açıdan yaklaşan araştırmacılardan bir diğeri de Clay Shirky’dir. İnternetin özgürleştirici yapısına vurguda bulunan Shirky, geleneksel medyanın haber yapma pratiği ile interneti kıyaslar. Ona göre, geleneksel medya mensupları aylarca bir haberin peşine düşüp, fikri takibini gerçekleştirirken; günümüzde gönüllü olarak hızlı bir şekilde bilgiler paylaşılabilmektedir. Ayrıca, geleneksel medyada eşik bekçiliğine atıfta bulunarak medya profesyonellerinin önemsiz olarak nitelendirip, ötelediği haberlerin sosyal medyada en ön sırada dolaşıma girebileceğine dikkat çekmektedir (Çakır, 2015: 25). Bu bağlamda, sosyal medyanın eşik bekçiliği olgusunu tamamen ortadan kaldırmamakla birlikte, geleneksel medyada yer verilmeyen ya da ikinci plana itilen kesimlerin de sesini duyurmak için etkili bir araç olduğu söylenebilir.

İnterneti olumlu bakış açısıyla değerlendiren bir diğer düşünür Yoneji Masuda, Kompütopya (Computopia) terimiyle günümüz yeni toplumsal biçimini betimlemektedir. Masuda'ya göre, enformasyon toplumu, endüstri toplumundan birçok özelliği farklılık gösteren yeni bir yapıdır. Endüstri toplumunda maddi değerlerin üretimi başat önem taşırken; enformasyon toplumunun itici gücü bilgidir. Buhar makinesinin yerini bilgisayar teknolojisi almıştır. Bu yeni yapıda ilerlemenin simgesi artık bilgisayarlardır (Akt. Uzun, 2013: 124).

Enformasyon toplumuna olumlu anlam yükleyenlerden bir diğer isim ise Alvin Toffler'dır. Toffler içinden geçmekte olduğumuz toplumsal değişim sürecini 'birinci dalga', 'ikinci dalga' ve 'üçüncü dalga' şeklinde olmak üzere dalgalar metaforu üzerinden betimlemektedir.

Toffler'a göre, birinci dalga tarımın başlangıcıyla doğmuştur. Daha sonra, endüstri devrimi ve getirdikleri ikinci dalganın doğuşuna yol açmıştır. Son olarak, günümüz toplumları ise insanlık tarihinin yeni bir dönemine tanıklık etmektedir. Üçüncü dalga 
metaforuyla betimlenen bu yeni dönem ile enformasyon toplumuna işaret edilmektedir. Tarım toplumu ve endüstri toplumları kendilerinden önceki kültür ve uygarlıklar üzerinden radikal değişiklikler yaratarak, yeni yaşam tarzlarının doğmasına yol açmıştır. Enformasyon toplumu olarak nitelendirilen bu üçüncü dalga da üretici tüketicilere dayanan yeni bir üretim süreci, yeni okul, ev ve aile yapıları gibi yeni bir yaşam tarzını beraberinde getirmektedir (2008: 15-17). Dahası, Toffler betimlediği bu yeni uygarlığa ilişskin şu aktarımlarda bulunmaktadır (2008:17):

$\mathrm{Bu}$ yeni uygarlık, eskisine meydan okurken, bürokrasileri devirecek, ulus devletlerin rolünü sınırlayacak ve emperyalizm sonrası yeni bir dünyada yarı bağımsız ekonomilerin oluşmasını sağlayacak. Bugün bildiklerimizden çok daha basit, çok daha etkili ama çok daha demokratik devletlerin kurulması mümkün olacak. Bu uygarlık, özgün bir dünya görüşüne, zaman, mekan ve mantığı ele alışında kendine has bir tarza sahip olacak. Daha da önemlisi, ileride göreceğimiz gibi Üçüncü Dalga uygarlığ1 üretici ile tüketici arasındaki tarihi engeli yıkacak ve yarının ekonomilerinde "üreten tüketicilerin" yaygınlaşmasını sağlayacaktır. Özellikle bu nedenle, tarihte görülmüş gerçekten ilk insan uygarlığına dönüşmesi - bizden alacağı biraz akıl sayesinde- mümkündür.

İnternet ve sosyal medya kullanımı katılımcı kültür bağlamında da olumlanmaktadır. Katılımcı kültür; etkileşim, ortak paylaşımda bulunma ve bireysel yayıncılığın ön plana çıkması gibi olgulara işaret etmektedir. Eş deyişle, web 2.0 teknolojisinin uygun ortam sağladığı katılımcı kültür; yurttaş katılımı, ortak paylaşım ve sosyal etkileşime katkıda bulunmaktadır (Karataş ve Binark, 2016: 429). Bu bağlamda, teknolojik determinist düşünürlerin büyük önem atfettiği web 2.0 teknolojisinin olanak sağladığı katılımc1 kültür, internete olumlu açıdan yaklaşan düşünürler tarafından yüceltilmektedir.

İnternete yönelik eleştirel yaklaşımlar ise dijital uçurum, nefret söylemi, dijital emek, kullanıcıların metalaşması, internet ve demokrasi ilişkisi, internetin bir gözetim aracı olarak kullanılması gibi olgular çevresinde toplanmaktadır. Christian Fuchs, Evgeny Morozov, Jean Baudrillard ve Paul Virilio, internete eleştirel açıdan yaklaşan isimler arasında yer almaktadır.

İnternet ve sosyal medya kullanımına eleştirel yaklaşanların önemle üzerinde durdukları noktalardan biri dijital uçurumdur. Kişiler, hane halkı ve işletmeler arasındaki boşluğa dikkat çeken dijital uçurum: Farklı sosyoekonomik düzeydeki kişiler, hane halkı ve işletme ya da ülkelerin bilgi ve iletişim teknolojilerine erişimde yaşadıkları eşitsizliği ifade etmek için başvurulan bir kavramdır (OECD, 2001: 5). Dünya genelinde dijital uçurum oldukça önemli bir soruna dikkat çekmektedir. Dijital uçurum terimiyle ifade edilen sadece kaç kişinin bilgisayara sahip olduğu ya da internete erişip sağlayıp sağlayamadığı değil, dijital uçurumun diğer eşitsizliklere göre daha geniş bir alanda yayılım göstermesi ve dahası mevcut diğer eşitsizlikleri daha da derinleştirebilmesidir (Öztürk, 2005: 112). Bu sebeple, Türkiye özelinde sosyoekonomik farklılıklar göz önünde bulundurulduğunda, internete eleştirel yaklaşan düşünürlerin önemle üzerinde durdukları bir konu olarak sayısal eşitsizlik önem kazanmaktadır.

Günümüzde internet ve sosyal medya alanında gerçekleştirdiği çalışmalarla en üretken akademisyenlerden biri olan Christian Fuchs, internet ve sosyal medyaya eleştirel ekonomi politik perspektiften bakmaktadır. 21. yüzyılda yeni bir toplumsal yapı içinde yaşadığımız şeklindeki görüşlerini, enformasyon toplumu, ağ toplumu, sanal toplum, siber toplum ve internet toplumu gibi kavramlar üzerinden açıklayan Fuchs, günümüz 
toplumlarının modern kapitalist toplumlar değil, yeni bir toplumsal yapı olduğuna dikkat çekmektedir (Çakır, 2014: 81- 82). Söz konusu olan bu kavramlar, bilginin üretiminde, insanların birbirleriyle kurdukları ilişkilerde ve daha birçok farklı alanda radikal değişikliklere sebep olmuştur.

Fuchs'un internet ve sosyal medyaya ilişkin en önemli saptamalarından biri bu teknolojilerin kullanıcılarının metalaştığı yönündeki düşüncesidir. Instagram'da bir paylaşımda bulunan ve diğer kullanıcılarla etkileşime geçen bir kişi ya da Facebook'ta arkadaş ekleyen bir kullanıcı reklam verenlere sunulan bir seyirci metası haline dönüşmektedir. Bu noktada, geleneksel medya ve yeni medya arasında ayrıma giden Fuchs, yeni medyada metalaşan izleyicinin geleneksel medyadaki izleyiciden farkının aynı zamanda içerik üreticisi olmasına dikkat çekmektedir (Fuchs, 2017: 73). Dolayısıyla, sadece basit paylaşımlarda bulunan ve diğer kullanıcılarla iletişime geçtiğini düşünen bu yeni ağ toplumunun yurttaşları bile büyük ticari şirketlerin ve reklam verenlerin temel hedefi haline gelebilmektedir.

İnternet ve internet dolayımlı teknolojilere eleştirel yaklaşan düşünürlerden biri de Evgency Morozov'dur. Morozov 2011 y1lında The Guardian'da yayınlanan "Facebook and Twitter are just places revolutionaries go" başlıklı yazısında, internete olumlamacı perspektiften bakanların dayanak noktalarından birini oluşturan internetin demokrasi ile ilişkisine eleştirel bir bakış açısıyla yaklaşmaktadır. Arap Baharı'nı örnek vererek tartışmasını yürüten Morozov, Facebook ve Twitter gibi dijital araçların sadece birer temel araç olduğunu ve gerçek dünya aktivizminin çabasının gözardı edilmemesi, birlikte değerlendirilmesi gerektiğini belirtmektedir. Bu ifadelerle Morozov, internet ve sosyal medyanın tek başına bir toplumsal hareketin destekçisi olamayacağını belirmektedir. Dolayısıyla, internet ve sosyal medyanın toplumsal hareketler noktasında zayıflığına dikkat çekmektedir (2011).

İnternet ve sosyal medyaya ilişkin eleştirilerden biri de internetin bir gözetim aracı haline gelmesi üzerinedir. Dann Laughey’e göre, günümüz toplumunu nitelendirmek için kullanılan enformasyon toplumu tezi, özellikle son yıllarda gözetim toplumuna evrilmiştir. İnternet aracılığıyla gerçekleştirilen gözetimin farklı boyut ve amaçları olmakla birlikte, bunların en başında küresel enformasyon şirketlerinin ticari amaçlı gerçekleştirdikleri gözetim gelmektedir (Aktaran: Çakır, 2015: 36).

Bir başka deyişle, özellikle internet ve sosyal medya üzerinden gerçekleştirilen gözetim sonucu dijital gözetim toplumu denilen yeni bir toplumsal yapı belirmiştir. Gözetime dayalı bu yeni toplum yapısı, 'panoptikon, sinoptikon ve süper panoptikon' gibi aşamalardan geçerek internet ve sosyal medya aracılığıyla herkesin herkesi gözetlediği bir yapıya işaret eden 'omniptikona' ulaşmıştır. Bu yeni dijital gözetim toplumunda, küresel enformasyon şirketleri, kamu kuruluşları ve sosyal medya kullanıcıları gibi öznelerden oluşan çeşitli gruplar farklı amaçlarla birbirlerini gözetlemektedirler. Küresel şirketler, internet ve sosyal medyadan yararlanarak daha fazla kar elde etmeyi amaçlarken, kamu kuruluşları toplumsal kontrol ve güvenlik gibi amaçlarla bu yola başvurmaktadır. Öte yandan, sosyal medya kullanıcıları ise yine kontrol etme ya da kişisel haz sağlama gibi gerekçelerle diğer kullanıcıları gözetlemekte ve gözetlenmektedirler (Kalaman, 2019: 576). 
Gözetimin yanı sıra yeni iletişim teknolojilerinin kontrol edilmesi zor birtakım olumsuz başka sonuçları da dikkat çekmektedir. Bunlar; nefret söylemi, şiddet ve şiddete dayalı ilişsilerin üretimi şeklinde kendini göstermektedir. Şiddet yeni iletişim teknolojileri aracılığıyla dışarıya açılabilmekte ve seyirci toplayabilmektedir (Kar ve Güven, 2016: 316). İnternet dolayımlı nefret söylemi, çeşitli sosyal paylaşım sitelerinde üretilen içerikler, haber siteleri, kullanıcı yorumları ve e-postalar aracılığıyla üretilmektedir.

Öte yandan, internet ve sosyal medya aracılığıyla üretilen nefretin takibi oldukça zor gerçekleşmektedir. Herhangi bir sosyal medya mecrasında gerçek ya da sahte bir profil aracılığıyla üretilen şiddete dayalı bir içerik saniyeler içerisinde yayılabilmekte ve dünyanın farklı bölgelerinden kullanıcılara ulaşabilmektedir. Bu durum, internete olumlu açıdan yaklaşan düşünürlerin atfettiği katılımcı kültür, bireysel yayıncılığı yükselişi gibi olguların istenmeyen birer yansıması olarak kabul edilebilir.

İnternet ve sosyal medyaya ilişkin eleştirilerin yoğunlaştığı bir diğer nokta ise dezenformasyondur. "Bilgi çarpıtma" (TDK, 2020) olarak tanımlanan dezenformasyon, internet ve sosyal medyanın yaşantımıza girmesiyle farklı bir boyut kazanmıştır. İnternet ve sosyal medyanın bireysel yayıncılığa olanak sağlayan yapısı aynı zamanda dezenformasyon terimini de gündeme getirmektedir.

Geleneksel gazetecilik pratiğinde bir "haberin doğruluğunu kanıtlama (verification)", farklı haber kaynaklarını karşılaştırarak denetim gerçekleştirme şeklinde ifade edilmektedir. Ayrıca, haberde geçen adlar, yerler ve diğer ayrıntıların doğruluğu teyit edilebilmektedir (Tokgöz, 2012: 266). Ancak, internet ve sosyal medyanın yapısal özellikleri bu duruma olanak tanımamaktadır. İnternet ve sosyal medyaya olumlamac1 perspektiften yaklaşanların ön plana çıkardığı bireysel yayıncılığın yükselişi, olgusu çeşitli durumlarda sosyal medyada dezenformasyona sebep olabilmektedir.

Paul Virilio ve Jean Baudrillard gibi düşünürler de teknoloji ve teknolojinin geçirdiği değişimleri eleştirel bir bakış açısıyla ele almaktadırlar. Virilio’ya göre, günümüzde teknoloji bir devinim içerisindedir ve bugüne kadar eylemsel anlamda harekete geçmemek bir tür problem kabul edilirken, teknolojinin kazandığı ivme sayesinde her şeyi ekran karşısından gerçekleştirebilmek mümkündür. $\mathrm{Bu}$ durum ise yeni iletişim teknolojilerine ait özellikler arasında sayılan zamansız ve mekansız olma durumunun bir diğer yüzüdür. Eşdeyişle, aynı anda her yerde bulunma ve aşırı algılama durumlarının birer yansımasıdır. $\mathrm{Bu}$ noktada ise zamansız ve mekansız olma durumlarının önemsiz kıldığı süre duygusu ise aslında toplumsal yaşamdır (A. Mattelart ve M. Mattelart, 2017: 144).

Virilio, yeni iletişim teknolojilerinin insan duyuları üzerinde de ciddi olumsuz etkileri olduğuna işaret etmektedir. Teknoloji, iletişim ve hız arasında bağlantılar kuran teorisyen, internet ve sanal gerçekliğin bir yeni iletişim biçimi olduğu yönündeki görüşleri reddetmektedir. İnternet, yeni iletişim teknolojileri ve bu teknolojilerin getirileri modernitenin abartılması ve teknolojik fundamentalizmin hakimiyetinden ibarettir (Stevenson, 2008: 323).

Teknolojiye ilişkin iyimserliği paylaşmayan bir diğer düşünür olan Baudrillard, günümüz toplumlarını; sanal ve hipergerçeklik, simülasyon ve tüketim toplumu gibi 
kavramlar üzerinden tanımlamaktadır. Baudrillard'a göre, günümüzde hakikat ile doğrudan ilişkisi kalmamış yapay bir üretim sonucu oluşturulmuş bir hipergerçeklik yani simülasyon içinde yaşanmaktadır (2018: 14- 15). Modern toplumlarda gerçeğin yitirildiğine dikkat çeken Baudrillard, bu görüşleri doğrultusunda kitle iletişim araçlarını da eleştirel bir bakış açısıyla ele almaktadır. Ona göre, kitle iletişim araçlarının insanlara sunduğu gerçeklik, yeniden üretilmiş ve kurgulanmış bir gerçekliktir. Medya, dünyaya ilişkin imgeler sunarken; hakikati göstermemekte, hakikatin simulakrını sunmaktadır (2012: 26). Kaldı ki televizyonun, dünyayı oldukça basite indirgenmiş bir biçimde toplumsal gerçeklik parçacıklarına ayırarak tüketime sunduğu ileri sürülmektedir. Kişiler, evlerinden, oturma odalarından bir ekran aracılığıyla, toplumsal bağlamından koparılmış bir gerçekliği izlemektedirler (Stevenson, 2008: 264). Baudrillard'ın hipergerçeklik ve simülasyon kavramları etrafında şekillendirdiği teknolojiye yönelik eleştirilerini internet ve sosyal medyaya yöneltmek mümkündür. Bu bağlamda, internet ve sosyal medya dolayımlı günümüzde hakikatin yerini bir sanal gerçeklik patlamasına bıraktığ 1 görülmektedir.

Özetle, internetin temellerinin atıldığ ilk zamanlardan günümüze internet ve sosyal medya bağlamında gerçekleştirilen çalışmalar, olumlu bakış açısını paylaşan teknolojik determinist düşünceler ve onlara karşıt olarak internet ve sosyal medyaya eleştirel yaklaşan düşünceler olmak üzere iki kutupta toplanmıştır.

\section{Sosyal İzolasyon ve Gönüllü Karantina}

Tarihsel süreçte insanlar ve toplumlar üzerinde yıkıcı etkileri olan birçok salgın hastalıkla mücadele edilmiştir. Bu hastalıklardan bazıları; ilk olarak 1817 yılında Hindistan'da ortaya çıkan ve dünyaya yayılan Kolera (Medicalpark.com, 2020), 19181920 yılları arasında yaşanan İspanyol Gribi (Bbc.com, 2020), 1968 yılında ortaya çıkan Hong Kong gribi (Ntv.com, 2020), 1970'lerin ortalarında Orta Afrika'da ortaya çıkan Ebola (Medicalpark.com, 2020), 2003 yılı Şubat sonlarında Asya, Kuzey Amerika ve Avrupa'da ilk olarak ortaya çıkan SARS (Bilheal.Bilkent, 2020), 2009 yılında ortaya çıkan Domuz Gribi (Medicalpark.com, 2020) ve 2019 yılının son günlerinde ilk olarak Çin'in Vuhan kentinde ortaya çıkan ve kısa sürede etkisi tüm dünyada hissedilen yeni tip koronavirüs (Covid-19).

Türkiye'de 11 Mart 2020 tarihinde Sağlık Bakanı Dr. Fahrettin Koca’nın bir kişiye Covid-19 teşhisi konulduğunu kamuoyuna duyurmasıyla hastalık Türkiye gündemine yerleşmiş ve Türkiye vatandaşları için farklı boyut kazanmıştır (Euronews.com, 2020). Dünyada birden fazla ülke ve kıtada birçok ölüme sebep olan Covid-19, toplumların yaşam biçimleri üzerinde de etkili olmuştur.

Bu doğrultuda, koronavirüs önlemleri kapsamında salgın hastalıklarla mücadelede son derece önemli olan sosyal izolasyon ve gönüllü karantina terimleri gündeme gelmiştir. Bu bağlamda, Koca'nın "koronavirüs, alacağımız tedbirlerden güçlü değildir. Bir hasta topyekun risk değildir. Karantinaya alınmış bir hasta toplumu tehdit edemez" (Euronews. com, 2020) ifadeleriyle sosyal izolasyon ve gönüllü karantinanın önemine salgının ilk 
günlerinden itibaren dikkat çekilmiştir. Öte yandan, "evdekal”, "evdekalTürkiye" ve "evdehayatvar" gibi sloganlar birçok kamu kuruluşu, televizyon kanalı, internet ve sosyal medya kullanıcıları tarafından kullanılarak, sosyal izolasyonun önemi vurgulanmıştır.

Bu süreçte, 65 yaş üzeri ve 20 yaş altı olmak üzere iki ayrı yaş grubu için Covid-19 önlemleri kapsamında sokağa çıkma yasağı ilan edilmiştir. Öte yandan, diğer yaş grupları için ise sosyal izolasyon ve gönüllü karantina kavramları söz konusu olmuştur.

Literatürde sosyal izolasyon, evde izolasyon, kendini izole etmek gibi birçok farklı kavramla izolasyon terimine işaret edilmektedir. Sosyal izolasyon terimi temel olarak, "grip ve tüberküloz gibi havadan bulaşan hastalıkların yayılmasının önüne geçmek için kişinin kendini toplumdan kısmi veya tamamen uzaklaştırması" (Hürriyet.com.tr, 2020) şeklinde tanımlanmaktadır. Sosyal izolasyon süresince kamuya açık alanlar geçici süreyle kapat1labilmektedir.

Sosyal izolasyonu takip eden Türkiye'de de "evdehayatvar" sloganıyla dikkat çeken ve evde izolasyon teriminde de temel olan nokta, evde bulunmak şeklinde sosyal izolasyonun sağlanması anlamına gelmektedir. Bir başka izolasyon biçimi olan kendini izole etmek ise temel olarak İngiltere' deki kullanımıyla "evde kalmak ve egzersiz yapma dışında evden çıkmamak" (Bbc.com, 2020) şeklinde tanımlanmaktadır.

Karantina terimi ise "bulaşıcı bir hastalığın yayılmasını önlemek için belli bir bölgenin veya yerin kontrol altında tutulup giriş çıkışların engellenmesi biçiminde uygulanan sağlık önlemi” (TDK, 2020) şeklinde tanımlanmaktadır.

Sosyal izolasyon ve gönüllü karantina ile mümkün olduğunca fiziki ortamlarda biraraya gelinerek gerçekleştirilen iletişimi sınırlandırmak amaçlanmaktadır. Pandeminin insanlar üzerindeki etkileri sadece yaşama yönelik oluşturduğu tehditten kaynaklanmamaktadır. Hastalığın yayılmasını önlemek için uygulanan sosyal izolasyon ve gönüllü karantina gibi tedbirlerin kişilerin yalnızlaşması, özgürlüklerinden mahrum kalmaları ve engellenmiş hissetmeleri gibi olası etkileri ortaya çıkabilmektedir (Açıkerişim.Gelişim.edu.tr, 2020). Bununla birlikte, toplumsal yaşamdan izole olan kişilerin, internet ve sosyal medya aracılığıyla sanal ortamlarda biraraya gelmekte ve paylaşımlarda bulunmaktadırlar. Kaldı ki, internet ve sosyal medyanın gündelik yaşamda etkisinin yoğun bir şekilde hissedildiği günümüzde 2020 yılına ilişkin Türkiye' de internet ve sosyal medya kullanımına ilişkin veriler şu şekildedir:

İngiltere merkezli bir global sosyal medya ajansı olan We Are Social ve Kanada merkezli Hootsuite tarafından yayınlanan Dijital 2020 (Wearesocial.com, 2020) raporuna göre, Türkiye ortalama 62 milyon internet kullanıcısı ile nüfusun yüzde 74'üne denk gelen bir oranla internet kullanmaktadır. 54 milyon aktif sosyal medya kullanıcısı ise Türkiye nüfusunun yüzde 64'üne denk gelmektedir. 16-64 yaş arası internet kullanıcılarının günlük internet kullanımı 7 saat 29 dakika olarak belirlenmiştir. İnternet üzerinden TV içeriği izleme oranı ise yüzde 62'dir. Mobil internet kullanımı ise günlük 4 saattir. Aynı rapordaki sosyal medya kullanım verilerine bakıldığında, 16-64 yaş arası kullanıcılar ortalama olarak günde 2 saat 51 dakika gibi bir süreyi sosyal medyada geçirmektedir. Kişi başına düşen sosyal medya hesabı sayısı ise 9.1'dir. Bu oran dünyada 8.6 'dır. İş 
amaçlı sosyal medya kullanımı yüzde 44'tür. Türkiye'nin genel olarak tüm kullanım yüzdelerinde dünya ortalamasının üzerinde yer aldığg görülmektedir.

Yeni tip koronavirüs (Covid-19) sonrası kişilerin sosyal izolasyonu sağlamak amacıyla zamanlarının büyük çoğunluğunu evlerinde geçirmeleri son dönem internet kullanım oranlarına da yansımıştır. İnternet Değişim Operatörü DE-cIX International CEO'su Ivo A. Ivanov pandemi sürecinde internet kullanımına ilişkin şu aktarımlarda bulunmuştur:

İnsanların COVID-19 nedeniyle kendilerini olağandışı bir durumda bulmalarıyla internet, salgından önceki duruma göre çok daha önemli bir rol oynamaya başladı. Günümüz toplumlarında, iş ve günlük akış içinde internet zaten olmazsa olmaz ama evlerde izole olmak ve küresel bir salgın tehlikesi ile karşı karşıya kalmak hem interneti daha mühim hale getirdi hem de kullanıcı tarafinda farklı eğilimlerin oluşmasına yol açtı. Son yıllarda yapılan analizlerde internette en çok rağbet gören içeriklerin videolar olduğu çok defa ortaya çıktı. Korona günlerinde veri trafiğine baktığımızda da veri akışının daha çok videolar üzerinden gerçekleştiğini görüyoruz... (Hürriyet.com, 2020).

Covid-19 pandemi sürecinde dünya genelinde internet kullanım oran ve eğilimlerine yansıyan çeşitli değişikliklerin bir benzeri Türkiye'de görülmektedir. Bu doğrultuda, Türkiye'deki internet servis sağlayıcılarından edinilen bilgiye göre, gündüz saatlerinde internet kullanımında yüzde 50 oranında bir artış olduğu görülmektedir (Habertürk.com, 2020). Bu doğrultuda, Covid-19 pandemi sürecinde farklı niteliklere sahip yurttaşların internet ve sosyal medya kullanım alışkanlıklarının ne yönde olduğunun saptanması önem taşımaktadır.

\section{Bulgular ve Yorum}

Bu başlık altında katılımcılarla yapılan yarı yapılandırılmış derinlemesine görüşme sonuçları belirlenen temalar çerçevesinde değerlendirilmiştir.

\section{Salgın Döneminde Değişen İnternet ve Sosyal Medya Kullanım Alışkanlıkları}

$\mathrm{Bu}$ bölümde katılımcılara, salgın döneminden önce ve salgın sirasında internet ile sosyal medya kullanım alışkanlıklarında bir değişiklik olup olmadığ 1 sorulmuştur. Genel olarak katılımcıların çoğu özellikle zaman anlamında sosyal medya ve internet kullanımının sosyal izolasyon döneminde arttığını ifade etmişlerdir.

Katılımcıların çalıştıkları alanların evden iş yapmaya uygun olduğu veya eğitim hayatlarını hâlâ sürdürdükleri söylenebilir. Dolayısıyla sosyal izolasyon ve gönüllü karantina döneminde genel olarak internet ve sosyal medya kullanımı artmıştır. Akademisyen olan E4, internet ve sosyal medyayı etkin kullandığını ancak sosyal medyada geçirdiği zamanın artmadığını ifade etmiştir. Salgın döneminde yapamadığı diğer kültürel aktivitelere yöneldiğini söyleyen E4, müzikle uğraştığını, kayıt yaptığını ve daha fazla kitap okuduğunu belirtmiştir. Ancak gündem takibi için özellikle twitterı salgın döneminde daha fazla kullandığını da sözlerine eklemiştir. 
Enformasyon toplumunda sosyal medya, özellikle twitter, gündemi takip etmek için önemli bir araç haline gelmiştir. Özellikle hızlı bilgi akışı ve olaylardan anında haberdar olma durumu twitterın önemli bir üstünlügüdür. Günümüzde gazeteciler, resmi devlet kurumları ve siyasiler twitterı etkin şekilde kullanmaktadır. Sağlık Bakanı Dr. Fahrettin Koca da koronavirüs salgını ile ilgili bilgilendirmeleri resmi twitter hesabı üzerinden yapmaktadır. Dolayısıyla haber ve gündem takibinde twitterın diğer sosyal medya sitelerine göre önemli bir üstünlügünün olduğunu söylemek gerekir.

K1 ve K3, salgın döneminde gündemi takip ederken sosyal medyayı salgın döneminden öncesine göre daha fazla kullandıklarını ifade etmişlerdir. K1, salgın dönemi ve salgından önceki sosyal medya kullanım alışkanlıklarını karşılaştırırken şu ifadeleri kullanmıştır: "Takip ettiğim pek çok içerik değişti. Salgından önce daha çok eğlence amaçlı kullandığım sosyal medyayı özellikle gündemi takip etmek için kullanmaya başladım. Gündemi takip etmek için de en uygun araç sanırım twitter." Etüt merkezinde öğretmenlik yapan ve salgın dolayısıyla uzaktan eğitim yöntemiyle çalışmaya devam eden K3 de benzer şekilde şu ifadeler kullanmıştır: "Zaman açısından sosyal medya kullanım alışkanlığ 1 kesinlikle değişti, ciddi bir artış var. Bu günlerde kafamda tek soru var, acaba ne oldu ve ne olacak? Bunu öğrenmenin en hizlı yolu da sosyal medya. Gündemi takip etmek için salgından önce sosyal medyayı bu kadar kullanmıyordum.”

Gündemi ve gündelik haberleri takip etmek önemli bir ihtiyaçtır. Koronavirüs salgını döneminde bireyler gündemi takip etmek için interneti ve özellikle twitterı kullanmışlardır. Twitter anlık haber takibi konusunda diğer sosyal medya sitelerine göre daha hızlı ve işlevsel bir site olarak görülmektedir.

İnternet ve sosyal medya, günümüzde sadece gündemi takip etmek için değil farklı aktiviteler için de kullanılabilmektedir. Avukatlık yapan E5, gündemi takip etmek dışında da salgın döneminde sosyal medya kullanımında bazı değişikliklerin olduğunu ifade etmiştir. Haber takibi için daha sık twittera girdiğini söyleyen E5, diğer insanlardan ve arkadaşlarından haberdar olmak için daha sık instagrama girdiğini ve daha önceden izlemediği kadar film, dizi ve video izlediğini söylemiştir. Bunun için de genellikle youtube veya netflix kullandığını belirtmiştir. İnternet ve sosyal medya, geleneksel medya araçlarına göre farklı işlevleri bünyesinde barındırır. E5 de salgın sırasında bu işlevlerden yararlandığını ifade etmiştir.

K5, salgın döneminden önce de sosyal medyayı çok sevdiğini ve yoğun şekilde kullandığını, salgın sırasında da bunun aynı şekilde devam ettiğini söyleyerek şu ifadeleri kullanmıştır:

Benim sosyal medya kullanım alışkanlıklarımda herhangi bir değişiklik olmadı. Yani her zamankinden daha çok ya da daha az kullanıyorum diyemem. Her zamanki rutinimde nasılsa aynı şekilde devam ediyor. Sosyal medyayı çok seviyorum ve aktif bir şekilde de kullanıyorum. Her gün düzenli olarak saat 7'de uyanırım. Kahvem, müziğim ve twitter hesabımla güne başlarım. Belirlediğim birkaç ülke var, onlara ve Türkiye gündemine bakıyorum. Ardında da okumalarımı yapar iki saat sonra da günlük koşuşturmalarıma başlarım. Krantina öncesinde nasılsa karantina boyunca da aynı devam ediyor...

K5'in sosyal medya kullanımını olumladığı görülmektedir. Sosyal medya kullanmaktan ve bunu bir yaşam biçimi haline getirmekten hoşnut olan K5'in salgın 
öncesi ve salgın sonrası internet ve sosyal medya kullanım alışkanlıklarında herhangi bir değişiklik olmamıştır.

K6, salgın döneminden önce eleştirel olarak baktığı sosyal medyaya, özellikle twittera, gündemi takip etmek için sık bir şekilde girdiğini ifade ederek şu cümleleri kullanmıștır:

İnternet ve sosyal medya kullanım alışkanlıklarımda değişiklik oldu. Özellikle yurt dışı yayılımı takip edebilmek için güvenilir uluslararası haber kaynaklarını, daha anlık bilgiler için twitterda farklı muhabirleri daha sık takip etmeye başladım. Twitter, genelde üzerime haberlerin, iletilerin yığıldığı ve yanlış bilginin sıklıkla ortaya çıktığı bir platform olduğu için pek kullanmamaya çalıştığım bir araç olmasına rağmen; toplumsal olaylar olduğunda en güncel bilgileri doğru ya da yanlıș bulabileceğim bir yer olduğundan hemen yine sarıldığım bir sosyal medya mecrası oldu. Uzun zamandan sonra yeniden twitter takip eder oldum...

K6, haber takibi ve sosyal medya ortamındaki dezenformasyon ile ilgili önemli noktalara değinmiştir. İnternet üzerinden gündelik haber takibi yaparken güvenilir kaynaklara erişmek ve haberlerin doğruluğunu takip etmek önemlidir. Ayrıca twitter ve diğer sosyal medya mecralarında dezenformasyonun yoğun şekilde olduğu unutulmamalıdır. Web 2.0 teknolojisi herkesin içerik üretmesine ve bu içeriği dolaşıma sokmasına olanak vermektedir. Dolayısıyla, internet kullanıcılarının internetteki haber ve bilgilerin doğruluğunu teyit etmesi gerekir. Özellikle olağanüstü dönemlerde buna daha fazla dikkat edilmelidir. Toplumun panik halinde olduğu dönemlerde yanlış olan bir haberin yayılması tehlike oluşturabilir.

Aşırı internet ve sosyal medya kullanımı gündelik yaşamda bazı sorunların ortaya çıkmasına neden olabilmektedir. Özellikle zaman yönetimi açısından aşırı sosyal medya kullanımı bazı olumsuzluklar ortaya çıkarmaktadır. K4, gönüllü karantina döneminde sosyal medya ve internette geçen aşırı zaman sebebiyle bazı sorumluklarını yerine getirmekte zorlandığını ifade etmiştir. Lisans son sınıf öğrencisi olan K4, internet ve sosyal medyada işe yaramayan pek çok bilgi ile zaman zaman vakit kaybettiğini ve zaman yönetimi yapmakta zorlandığını sözlerine eklemiş̧tir. Yüksek lisans öğrencisi olan E3 de internet ve sosyal medyada harcadığ1 vaktin neredeyse 3 veya 4 kat arttığın1 söyleyerek bazen gereksiz bilgilerle meşgul olduğunu ifade etmiştir. Alışveriş merkezi çalışanı olan ve ücretli izne çıkarılan, aynı zamanda da yüksek lisans öğrencisi olan K2 de gönüllü karantina döneminde boş zamanlarının büyük bir çoğunluğunu sosyal medyada geçirdiğini ifade etmiş; ancak bunun zaman yönetimi anlamında kendisine bir sorun yaratmadığını belirtmiştir.

Doktora öğrencisi olan E1, gönüllü karantina ve sosyal izolasyon döneminde interneti daha fazla kullandığını ifade etmiştir. Salgın öncesinde özellikle akşamları bir iki saat yürüyüş yaptığını söyleyen E1, salgınla birlikte fiziksel aktivitenin azaldığını ve bunun yerine sosyal medyaya olan ilginin arttığını söylemiştir. Fiziksel aktivite, sağlıklı yaşam için oldukça önemlidir. Pek çok uzman haftada 3 veya 4 gün spor yapılmasını önermektedir. Özellikle yürüyüş yapmak sağlık için önemlidir. Sosyal izolasyon ve karantina döneminde fiziksel aktivitenin azaldığı söylenebilir. Ancak bu noktada da internet ve sosyal medyanın avantajlarını kullanmak mümkündür. İnternet ve sosyal medyada "evde spor" başlıklı pek çok egzersiz videosu bulunmaktadır. Fiziksel hareketin azaldığ 1 dönemlerde bu içeriklerden yararlanılabilir. 
Gazetecilik yapan E1, salgın döneminde evde daha fazla kalmak durumunda olduğunu ve özellikle sosyal medya üzerinden kurduğu iletişimin arttığını ifade etmiştir. Hem iş için hem de ailesiyle iletişimde sosyal medyayı kullandığını söyleyen E1, bu dönemde önemli bir medya aracına dönüştügünü belirtmiştir.

Bu bölümde, katılımcılara salgın dönemi öncesi ve salgın sırasındaki internet ve sosyal medya kullanım alışkanlıklarında farklılık olup olmadığı sorulmuştur. Genel anlamda salgın sirasında gündeme gelen sosyal izolasyon ve gönüllü karantina döneminde, internet ve sosyal medyanın özellikle zaman anlamında daha fazla kullanıldığ anlaşılmıştır. Bu duruma olumlu yönde bakan katılımcılar olduğu gibi olumsuz yönde bakan katılımcılar da olmuştur. Bir başka sonuç ise haber ve gündemi takibi bağlamında ortaya çıkmıştır. Salgın döneminden önce haber takibi ve gündem için internet ve sosyal medyayı bu kadar sık kullanmayan katılımcılar, özellikle salgın döneminde güncel bilgi ve veriler için internet ve sosyal medyayı daha fazla tercih etmeye başlamışlardır.

\section{Sosyal İzolasyon ve Gönüllü Karantina Döneminde İnternet ve Sosyal Medya Kullanım Amaçları}

İnternet ve sosyal medya, geleneksel kitle iletişim araçlarına göre farklı kullanım işlevlerini birarada taşımaktadır. İnternet ve sosyal medya oldukça farklı amaçlarla kullanılabilir. Dolayısıyla bu bölümde katılımcıların sosyal izolasyon ve gönüllü karantina döneminde hangi amaçlarla interneti ve sosyal medyayı kullandıkları ortaya çıkarılmaya çalış1lmıştır.

Covid-19 dönemi bireylerin eve kapandıkları ve kendi kendilerine vakit geçirdikleri bir dönem olmuştur. Bazı teknolojik araçlar ve uygulamalar gündelik yaşamda bireylere daha fazla eşlik etmektedir. İnternet ve sosyal medya bu anlamda, bireylerin yoğun şekilde kullandığı teknolojilerin başında gelmektedir.

$\mathrm{Bu}$ bölümde araştırmaya katılan katılımcıların benzer cevaplar verdikleri görülmüştür. Dolayısıyla bu bölümde, genel bir değerlendirme yapılmış ve diğer katılımcılara göre farklı cevaplar veren 2 katılımcının görüşleri paylaşılmıştır.

Sosyal izolasyon ve gönüllü karantina döneminde katılımcıların çoğu interneti ve sosyal medyayı gündemi takip etmek için kullandıklarını ifade etmişlerdir. Covid-19 döneminde internet ve sosyal medya gündemi takip etmek için önemli araçlar olmuştur. Bunda, bireysel kullanıcıların yanında devlet yöneticilerinin ve sağlık bakanının da salgın ile ilgili duyuru yapmak için sosyal medyayı kullanması etkilidir. Sağlık Bakanı Fahrettin Koca, ülkemizde ilk vakanın görüldüğü tarihten itibaren düzenli olarak hem salgın verileri hem de farklı içeriklerle sosyal medya üzerinden paylaşım yapmaktadır.

Covid-19 salgını dolayısıyla, ülkemizde ortaöğretim ve yükseköğrenimde uzaktan eğitime geçilmiştir. Bu kararın en büyük amaçlarından biri, öğrencilerin kalabalık yerlerden uzak durarak kendi evlerinde özellikle ailelerinin yanında daha güvende olmalarını sağlamak olmuştur. Araştırmaya katılan ve eğitimlerine devam eden katılımcılar, uzaktan eğitim için interneti kullandıklarını ifade etmişlerdir. Ayrıca makale okumak ve araştırma yapmak için de internetin kullanıldığ görülmüştür. 
Sosyal medyanın en önemli işlevlerinden biri bireylerarası iletişimi daha kolay hale getirmesidir. Çünkü sosyal medya üzerinden kurulan iletişim sırasında zaman ve mekân kavramı ortadan kalkmaktadır. Dolayısıyla yüz yüze gelmeden de sosyal medya üzerinden etkileşim kurmak mümkündür. Araştırma kapsamında görüşülen kişiler, sosyal izolasyon ve gönüllü karantina döneminde sosyal medyayı çevreleriyle iletişim ve etkileşim kurmak için kullandıklarını ifade etmişlerdir.

Araştırma kapsamında görüşme yapılan katılımcıların, interneti film ve dizi izlemek için yoğun şekilde kullandıkları saptanmıştır. Son dönemlerde internet üzerinden faaliyet gösteren film ve dizi izleme platformları oldukça popüler olmuştur. Covid-19 sürecindeki sosyal izolasyon ve gönüllü karantina döneminde bu platformların popülerliğini arttırdıkları söylenebilir. Netflix, pandemi döneminde dünya genelindeki abone sayısının 16 milyon arttığını açıklamıştır (Made for Minds, 2020).

Yüksek lisans öğrencisi olan ve aynı zamanda bir alışveriş merkezinde satış danışmanlığ1 yapan K2, sosyal izolasyon ve gönüllü karantina döneminde gündemi takip etmek dışında, instagram üzerinden yapılan canlı yayınları izlediğini ve kendisinin de canlı yayın yaptığını söylemiştir. Ayrıca görüntülü konuşmalar için de interneti kullandığını ifade etmiştir. Sosyal medya sitelerinin çoğu canlı yayın yapmaya olanak vermektedir. Sosyal izolasyon ve gönüllü karantina döneminde canlı yayın yapmak da popüler hale gelmiştir. Bu dönemde pek çok ünlü isim de sosyal medya üzerinden canlı yayın yapmıştır. Ayrıca bu dönemde ünlü isimler sosyal medya üzerinden konser düzenleyip, kitap okuma etkinlikleri de yapmıştır (Webrazzi.com, 2020).

Etüt merkezinde öğretmenlik yapan K3, sosyal izolasyon ve gönüllü karantina döneminde sosyal medya aracılığıyla sanata olan ilgisinin arttığını söyleyerek şu ifadeleri kullanmıştır:

Mesleğim dışında sanatla ilgilenmeye çalışıyorum. Özellikle resim ilgimi çekiyor. Kendim de bir şeyler çiziyorum ama çok amatörce. Bu süreçte resim sergilerini online olarak gezme olanağ bulduğum için mutluyum. Belki hayatım boyunca gidemeyeceğim bir sergiyi internet aracılığıyla gezme firsatı buldum. Her sabah kalktığımda, dünyanın herhangi bir yerindeki sergiye gidebiliyorum gibi oluyor.

Covid-19 sürecinde farklı sanatsal ve kültürel faaliyetlerin birçoğu internet üzerinden erişime açılmıştır. Bu durum, sosyal izolasyon ve gönüllü karantina döneminde bireylerin farklı aktivitelerde bulunmasını sağlamıştır. Müze, sergi ve sanat galerisi gibi mekânlara online olarak erişmek buna örnek olarak verilebilir.

Özetle, bu bölümde sosyal izolasyon ve gönüllü karantina döneminde internet ve sosyal medyanın kullanım amaçlarının neler olduğu vurgulanmıştır. İnternet ve sosyal medya Covid-19 sürecinde bazı fırsatlar yaratmıştır. Gündemi daha hızlı takip etme, sosyal medya kullanıcılarının canlı yayın yaparak kendilerini ifade etmesi ve kültürel faaliyetlere erişim bunlara örnektir. Bu firsatları değerlendiren katılımcıların olduğu görülmüştür. Ayrıca, sosyal izolasyon ve gönüllü karantina döneminde internet ve sosyal medya genel olarak iletişim, etkileşim, eğlence, online eğitim ve film, dizi izlemek için kullanılmaktadır. 


\section{Sosyal İzolasyon ve Gönüllü Karantina Döneminde İnternet ve Sosyal Medyanın Önemi-Kazandırdıkları}

İnternet ve sosyal medya enformasyon toplumunun vazgeçilmez unsurlarıdır. Kuşkusuz, her teknolojinin olduğu gibi internetin ve sosyal medyanın da hem olumlu hem de olumsuz özellikleri vardır. Covid-19 döneminde gündeme gelen sosyal izolasyon ve gönüllü karantina döneminde Türkiye'de internet kullanım oranlarında artış olmuştur (Trthaber.com, 2020).bBu bölümde, katılımcıların sosyal izolasyon ve gönüllü karantina döneminde kullanım oranları artan internete ve sosyal medyaya ilişkin tutumları ortaya çıkarılmıştır.

Covid-19 süreci, bireylerin psikolojik olarak etkilendiği bir süreç olmuştur. Sosyal izolasyon, gönüllü karantina ve insanlardan uzaklaşmak bireylerin teknolojik araçlarla daha fazla vakit geçirmesine neden olurken; internet ve sosyal medya gündelik hayatın merkezine yerleşmiştir. E2, psikolojik olarak bu süreçten pek çok kişinin etkilendiğini ve bunun etkilerini azaltmak için de internet ve sosyal medyanın kaçış olduğunu söylemiştir.

Sosyal izolasyon ve gönüllü karantina döneminde, internet ve sosyal medya bireylerin kendilerini geliştirebilecekleri bir alana da dönüşmüştür. K2 ve E3 bu konuda benzer görüş bildirmişlerdir. K2'ye göre özellikle sosyal medya, Covid-19 döneminde bireylere önemli kazanımlar sağlamıştır. K2 normalde çok fazla para ödeyerek ulaştığı çeşitli konser ya da spor antrenmanlarına sosyal medya sayesinde ücretsiz olarak erişebildiğini ifade etmişstir. Ayrıca, sosyal izolasyon ve gönüllü karantina döneminde insanların daha fazla beraberlik içinde olduğunu da sözlerine eklemiştir. E3 de bireylerin bu dönemde internet ve sosyal medya aracılığıyla kendilerini geliştirdiklerini gözlemlediğini belirtmiştir.

Covid-19 sürecinde yaşanan sosyal izolasyon ve gönüllü karantina döneminde, bireylerin normal akış içerisinde devam eden gündelik yaşamdaki zamanlarına göre daha fazla serbest zamanları olmuştur. Kuşkusuz bu serbest zaman evde vakit geçirme olanağ1 bulan kişiler için geçerlidir. Bu dönemde bazı resmi kurumlar online arşivlerini erişime açmıştır. K4 ve E5 bu konuya farklı açılardan dikkat çekmişlerdir. K4'e göre, TÜBİTAK ve bazı kütüphanelerin kaynaklarını erişime açması daha önceden ulaşılamayan pek çok yayına ulaşılmasını sağlamıştır. K4'e göre bu durum özelikle uzaktan eğitim sürecine geçen öğrenciler için büyük bir firsat yaratmıştır. E5 de erişime açılan online yayınlara dikkat çekmiş ancak bundan faydalanma konusunda eksiklikler olduğunu ifade etmiştir.

\footnotetext{
$\mathrm{Bu}$ dönemde internet ve sosyal medyada kişilere fayda sağlayabilecek alanlar oluştu. Ama ben çoğu kişinin odaklanıp şu yayını okuyayım, bunu araştırayım şeklinde davranabildiğini sanmıyorum. Elbette uzaktan eğitime geçen öğrenciler online yayınlardan yararlanmak durumundalar. Ama salgın korkusu bir yandan sosyal medya ve internette sürekli dikkatimizi dağıtacak bir şeylerin olması bir yandan bence bu alanlardan yararlanmayı olumsuz etkiliyor...
}

İnternet, farklı uyarıcıların ve eğlence içeriklerinin sıklıkla karşımıza çıktığı bir alandır. Dolayısıyla bu durum, internetten ve sosyal medyadan yararlanma konusunda problemler yaratabilmektedir. Salgın döneminde internetten ve sosyal medyadan yararlanmak, kişisel özelliklere göre değişiklik gösterebilir. K3, internetten ve sosyal medyadan doğru şekilde yararlanmanın tamamen kişisel özelliklerle ilgili olduğunu söylemiştir. K3'e göre günümüzde gerçeklik değişkenlik göstermektedir ve sosyal medya ile internetten yararlanmak bu teknolojilerin neresinden tutulduğuna bağlidır. 
Özellikle sosyal medyanın yeniden doğuş da intihar sebebi de olabileceğini söyleyen K3, hayatlarımızın ağlar aracılığıyla birbirine bağlı olduğunu ifade etmiştir.

İnternet ve sosyal medya dezenformasyonun eşdeyişle yanıltılmış ve yönlendirilmiş bilginin yoğun olarak kullanıma girdiği bir alandır. Dolayısıyla internet ve sosyal medya aracılığıyla gündemi takip ederken ulaştığımız bilgilerin ve haber kaynaklarının doğru olup olmadığını kontrol etmemiz gerekmektedir. E6, internetin bu özelliğine dikkat çekerek şu ifadeleri kullanmıştır:

Karantina döneminde, güvenilir bir kaynak olmamasından dolayı internetin bilgi anlamında herhangi bir kazanım teşkil etmediğini düşünüyorum; aksine bilgi alma anlamında son tercih olarak kullanıyorum interneti. Ancak mevcut iletişim kanalları içerisinde uzaktan eğitim ve insanların aile/akraba ile daha kolay ve çoklu görüşebilme yapabilme olanağından dolayı iletişim anlamında katkı sağladığını düşünmekteyim.

E6, internet ve sosyal medyanın hem olumlu hem de olumsuz özelliklerine vurgu yapmıştır. Günümüzde kullanılan internet teknolojisi ve sosyal medya web 2.0 temellidir. Web 2.0 kullanıcı temelli bir internet teknolojisi olup, internet kullanıcılarının içerik oluşturmasına ve içeriğe müdahale etmesine olanak vermektedir. Bu durum, internette ve sosyal medyada dezenformasyon oluşumuna da neden olabilmektedir. Bunun yanında, yeni teknolojilerin iletişim anlamında önemli bir üstünlügü bulunmaktadır. Görüntülü ve sesli konuşmayı aynı anda sağlayan akıllı telefonlar bireylerarası iletişime doğrudan katkı yapmiştır.

K1 ise E6'ya göre internetin ve sosyal medyanın, sosyal izolasyon ve gönüllü karantina döneminde insanların hayatına gözle görülür bir katkı yapmadığını söylemiştir. E6'ya göre, bu dönemde sadece içerikler fazlalaşmış ve işe yaramayan birçok paylaşımda bulunulmuştur. İnsanların can sıkıntısından sosyal medyayı daha fazla kullandıklarını ifade eden E6, faydalı şeylerle uğraşmak yerine sosyal medyanın tercih edildiğini belirtmiştir.

İnternette ve sosyal medyada faydalı içeriklerin yanında, sadece eğlence ve tüketime yönelik içerikler de bulunmaktadır. Özellikle sosyal medya, bireylerin sürekli olarak birbirini takip ettiği ve gözetlediği bir alana dönüşmüştür. Bu durum, etkin bir şekilde kullanılabilecek serbest zamanların boşa gitmesine de aracı olmaktadır.

Akademisyen olan E4, karantina döneminde sosyal medyanın farklı bakış açılarını daha iyi anlamımızı sağladığını söylemiştir. Gündelikyaşamda sınırlıbirçevredehayatımızı sürdürdügümüzü ifade eden $\mathrm{E} 4$, kendimize benzeyen ve aynı fikirleri paylaştığımız insanlarla vakit geçirdiğimizi belirtmiştir. E4, sosyal medya ve internette farklı insanların ve bakış açılarının olduğuna dikkat çekmiştir. Dolayısıyla bu görünürlüğün, farklı bakış açılarını anlama ve saygı duyma konusunda faydalı olduğunu sözlerine eklemiştir.

Sosyal medya ve internet farklı grupların, yaşam biçimlerinin ve düşüncelerin ortaya çıktığı bir alandır. Ağlar aracılığıyla farklılıkların görünür olması, zaman içinde diğer internet kullanıcılarının da bu farklılıkları görmelerini sağlamaktadır. Dolayısıyla bu durum, farklı bakış açıları ve yaşam biçimlerinin anlaşılmasına aracı olabilmektedir.

K6, sosyal izolasyon ve gönüllü karantina döneminde internetin ve sosyal medyanın olumlu özelliklerinin daha fazla ön plana çıktığını belirterek şu ifadeleri kullanmıştır: 
$\mathrm{Bu}$ dönemde en çok dikkat ettiğim şey, dayanışma ağlarının ortaya çıkması. Çünkü sosyal izolasyon moral olarak başa çıkılması güç bir süreç. Bu süreçte, normalde parayla ulaşılabilen pek çok etkinlik ve hizmet, internet ve sosyal medyayla evimize girdi. Müze gezileri, konserler bunlara örnek olarak verilebilir. İnternet, yapılan işleri hedef kitlemizle buluşturmamızı da sağladı. Ayrıca, pandeminin Türkiye'deki yayılma sürecinin yavaşlaması, internetin ve sosyal medyanın kullanıcılara sunduğu olanaklarla gerçekleşti diyebiliriz...

K6, sosyal izolasyon ve gönüllü karantina döneminde internetin ve sosyal medyanın bireylere olumlu katkılar yaptığını belirtmiştir. Kuşkusuz bazı etkinliklerin ücretsiz olarak erişime açılması veya bireylerin ağlar aracılığıyla kendilerini ifade etme konusunda olanak bulması olumlu durumlardır. Ancak bu ifadeleri kullanırken, Türkiye'deki internete erişim oranları, sayısal eşitsizlik ve kimlerin internetten nasıl yararlandığını da incelemek gerekmektedir.

$\mathrm{Bu}$ bölümde, sosyal izolasyon ve gönüllü karantina döneminde internetin kazandırdıkları, katılımcıların düşünceleri doğrultusunda değerlendirilmiştir. İnternetin ve sosyal medyanın, sosyal izolasyon ve gönüllü karantina döneminde farklı kullanım alanları ortaya çıkmıştır. Bu dönemde internet, gündelik hayattaki etkisini ve kullanım oranlarını arttırmıştır. Katılıcımların üzerinde durduğu önemli kazanımlardan biri, ücretsiz etkinliklerin dijital olarak sunulmasıdır. Müze gezileri ve konserler buna örnek olarak verilmiştir. Bu dönemde, bazı yayınların ücretsiz olarak erişime açılması da önemli bir kazanım olarak ifade edilmiştir. Özellikle, bu durumun uzaktan eğitim sürecine katk1 sağladığ kazanım olarak ifade edilmiştir. Son olarak ise sosyal medya ve internetin bireylerarası iletişimin etkili bir şekilde sürdürülmesine katkı sağladığı belirtilmiştir. Katılmcılar, sosyal izolasyon ve gönüllü karantina döneminde internetin ve sosyal medyanın bazı olumsuzluklara da neden olduğunu ifade etmişlerdir. Özellikle serbest zamanının artışıyla birlikte bireylerin daha çok eğlence içeriklerine yöneldiği üzerinde durulmuştur. İnternet üzerindeki dezenformasyon artışı ve bireylerin doğru bilgiyi ayıklamada güçlük çektiği de bir olumsuzluk olarak ön plana çıkmıştır. Son olarak ise sürekli paylaşım yapma isteğinin bireylerin internet ve sosyal medyadan yararlanma konusunda olumsuz etkilediği belirtilmiştir. Özetle, yeni dünya düzeninde internetin ve sosyal medyanın kullanım oranlarını ve etkisini arttıracağı bir gerçektir. Dolayısıyla bu teknolojilerin bireysel anlamda olumlu bir şekilde kullanılması önem taşımaktadır.

\section{Salgın Döneminde Dijital İçerik Takibi ve Üretimi}

Web 2.0 teknolojisinin en önemli özelliklerinden biri, kullanıcıların içeriğe müdahale edebilmeleri ve içerik üretmeleridir. Günümüzde internet kullanıcıları hem içerik üretmekte hem de bu içeriği tüketmektedir. Özellikle sosyal medya, içerik üretimi konusunda kullanıcılara pek çok firsat yaratmaktadır. Bu bölümde, salgın döneminde sosyal medya ve internet üzerinden içerik takibi ve üretimi konusunda katılıcımların düşünceleri doğrultusunda çözümlemeler yapılmıştır.

Katılımcılarla yapılan görüşmeler sonucunda, bütün katılıcımların dijital içerikleri takip ettikleri görülmüştür. Üretim konusunda ise 3 farklı grup ortaya çıkmıştır. Bunlar; dijital içerik üretmeyenler, hazırlık yapan ve üretim aşamasına geçmeyi düşünenler ve içerik üretimi yapanlar olarak sıralanabilir. 
E1, E3, K4 ve K5 dijital içerikleri takip ettiklerini; ancak herhangi bir üretim yapmadıklarını ifade etmişlerdir. E1, herhangi bir içerik üretmediğini; ama pandemi döneminde farklı bir ilgi alanına yöneldiğini ve bu konudaki içerikleri takip ettiğini ifade etmiştir. Japon örgü sanatı 'amigurimi' ye ilgi duyduğunu ve bu alandaki üretimleri takip ettiğini söyleyen E1, böyle bir ilgi alanına sahip olduğu için mutlu olduğunu belirtmiştir. E1'e göre, bu dönemde internet ve sosyal medyadaki içerikler artmıştır. E1, bireylerin özellikle can sıkıntısından dolayı, işe yaramayan, öylesine paylaşımlar yaptıklarını da söylemiştir.

E3 ve K5, içerik üretmeyen; ancak içerikleri takip eden katılımcılardır. İki katılımcı da genel anlamda üretilen içerikleri eleştirmişlerdir. E3 ve K5'e göre, yapılan pek çok paylaşım ve üretilen pek çok içerik sığ paylaşımlardan ibarettir. Ayrıca E3 ve K5'e göre, gereksiz abartı ve popüler olma isteği sosyal medyanın yeni modası haline gelmiştir. Günümüzde sosyal medya kullanıcılarının çoğu kendisini aldığı beğeni veya takipçi sayısı ile ifade etmektedir. Bu durum, enformasyon toplumunda gündelik yaşantının ağlar aracılığıyla sürdüğünün de bir göstergesidir. K4 ise sosyal medya ve internetteki dijital içerikler konusunda E3 ve K5'e göre farklı düşünmektedir. K4'e göre, sosyal izolasyon döneminde bireyler yetenekleri sergileme firsatı bulmuştur. Ayrıca bu dönemde internet üzerindeki faydalı ve kaliteli işler artmıştır.

E4, E5 ve K1 sosyal izolasyon ve gönüllü karantina döneminde dijital içerik üretme hazırlığında olduklarını belirtmişlerdir.

E4, sinema ile ilgilendiğini söylemiş ve bu alandaki içerikleri takip ettiğini ifade etmiştir. Dünya ve Türk sineması ile ilgili konu başlıkları biriktirdiğini söyleyen E4, bu alanda bir youtube kanalı açma düşüncesi olduğunu da sözlerini eklemiştir. E5, anksiyete sorununun pandemi döneminde fazlalaştığını ve bunu biraz olsa da azaltmak için özellikle youtube üzerinden terapi kanallarını izlediğini belirtmiştir. Dijital içerik üretme konusunda ise şu ifadeleri kullanmıştır: "Deneme tarzında yazılar yazıyorum. Henüz bunları yayınlamadım; ama bir blog sayfası açma düşüncem var."

İletişim alanında yüksek lisans yapan K1, olağanüstü bir dönem geçirdiğimizi ifade etmiş ve bu dönemde bireylerin yetenekleri doğrultusunda içerik üretmelerinin önemli olduğunu söylemiştir. Kendisinin de iletişim alanında akademik üretimler yapmak istediğini belirten K1, henüz kafasında kesinleşen bir şey olmadığını sözlerine eklemiştir.

Sosyal izolasyon ve gönüllü karantina döneminde; E2, E6, K2, K3 ve K6 içerik ürettiklerini belirtmişlerdir.

Yerel gazeteci olan E2, özellikle bilgilendirme notları ürettiğini ve yaşadığı kente dair haberleri paylaştığına dikkat çekmiştir. Bunun yanında, insanları eğlendirebilecek mesajlar ve paylaşımlar yaptığını sözlerine eklemiş̧tir. Salgın döneminde doğru habere olan ihtiyaç artmıştır. Özellikle sosyal medyadaki dezenformasyonun etkisinin azaltılması için, gazetecilerin kendi ürettikleri haberleri kişisel hesaplarından paylaşmaları önemlidir.

E6 ve K3 farklı türde dijital içerik üretimi yaparken, bu üretimden duydukları memnuniyetler benzerdir. E6, kişisel blog sayfasından kendi çektiği manzara ve gezi fotoğraflarını paylaşırken, beğeni ve olumlu geri bildirim aldıkça kendisini iyi 
hissettiğini ifade etmiştir. Benzer şekilde, K3 de sosyal medya hesaplarından okuduğu şiirleri paylaşmaktadır ve bundan haz duyduğunu belirtmiştir. K3, bu dönemde kişilerin kendilerini sosyal medya aracılığıyla var ettiğini ve bunun olumlu olduğunu söylemiştir.

$\mathrm{K} 2$, instagram aracılığıyla canlı yayın yaparak dijital içerik ürettiğini söylemiştir. İlk canlı yayınını İtalya'da yaşayan kardeşiyle yapan K2, özellikle salgının ilk zamanlarında İtalya'nın durumunu ve bizlerin alması gereken önlemleri takipçileriyle paylaşmak istediğini belirtmiştir. K2, yaptığı canlı yayınlarla ilgili şu ifadeleri kullanmıştır: "Kardeşimle yaptığım canlı yayın hoşuma gitti. Etkileşim almak, soruların gelmesi... Daha sonra da arkadaşlarımla müzik, spor ve farklı konularda canlı yayın yapmaya başladım. Genel olarak etkileşim almak güzel bir duygu." Sosyal medyanın en önemli özelliklerinden biri etkileşimdir. Etkileşim, bireylerarası iletişimin en önemli unsurlarındandır. Etkileşim, sosyal medya kullanımını gün geçtikçe arttırmaktadır.

İnternet ve sosyal medyanın önemli kullanım alanlarından biri de eğitimdir. İnternet ve sosyal medya, bireylere eğitimle ilgili pek çok fursat sunmaktadır. K6, sosyal izolasyon ve gönüllü karantina döneminde evde kalan çocuklar ve aileleri için etkinlikler üretip, bunları kendi sosyal medya hesaplarından paylaştığını belirtmiştir. Oldukça ilgi çektiğini ve olumlu geri bildirimler aldığını ifade eden K6, insanlara fayda sağlamanın kendisine mutluluk getirdiğini sözlerine eklemiştir.

$\mathrm{Bu}$ bölümde, katılımcıların sosyal izolasyon ve gönüllü karantina döneminde hangi içerikleri takip ettikleri ve içerik üretip üretmedikleri sorularına yanıt aranmıştır. Katılımcıların hepsi kendi ilgi alanları doğrultusunda farklı içerikleri takip etmektedir. Bunun yanında dijital içerik üretmeyenler, dijital içerik üretme hazırlığı ve düşüncesinde olanlar ile dijital içerik üreten katılımcılar vardır. Dijital içerik üreten katılımcıların; eğitim, fotoğraf, haber, edebiyat gibi farklı alanlarda dijital içerik ürettikleri görülmüştür. Dijital içerik üretme düşüncesi ve hazırlığı içerisinde olan katılımcıların ise kendi ilgi alanları doğrultusunda içerik üretme aşamasında oldukları tespit edilmiştir. Özetle web 2.0 teknolojileri, internet kullanıcılarının dijital içerik üretmelerine olanak vermektedir. Sosyal izolasyon ve gönüllü karantina döneminde bireyler kendilerini ifade etmek, yaşam biçimlerini sunmak ve başka insanlara fayda sağlamak için dijital içerik üretimi yapmaktadırlar.

\section{Sonuç ve Değerlendirme}

$\mathrm{Bu}$ çalışmada, yeni koronavirüs döneminde gündeme gelen sosyal izolasyon ve gönüllü karantina döneminde internet ve sosyal ağların kullanımının ne yönde olduğu değerlendirilmiştir. Çalışmada çevrimiçi yarı yapılandırılmış derinlemesine görüşmeler yapılmıştır. Farklı meslek ve yaşlarda 6 kadın 6 erkekle görüşülmüş ve çözümleme kategorileri tematik analizle belirlenmiştir. Görüşülen kişilerin gönüllü karantinayı ve sosyal izolasyonu uygulamalarına dikkat edilmiştir.

Yeni koronavirüs salgını bireylerarası temasla bulaşan ölümcül bir hastalıktır. $\mathrm{Bu}$ hastalıktan korunmanın en etkili yolu, dışarı çıkmamak ve kalabalık ortamlarda bulunmamaktır. Dolayısıyla evde kalmak ve evde vakit geçirmek, bu hastalıkla mücadele 
etmenin en temel yoludur. Salgının Türkiye'de ortaya çıtığı ilk günden itibaren, salgınla mücadele etmek için pek çok önlem alınmıştır. Bunun yanında uzun süreli bir sokağa çıkma yasağı uygulanmamış ve evde kal içerikli kampanyalar düzenlenmiştir. Dolayısıyla bu dönemde, dünyada olduğu gibi Türkiye'de de internet ve sosyal medyanın kullanım oranlarında artış olduğu tespit edilmişstir.

Bugün kullandığımız internet, web 2.0 temellidir. Web 2.0, bireysel internet kullanıcılarına etkileşim ve dijital içerik üretme olanağı vermektedir. Dolayısıyla bu özellikler internet ve sosyal medya kullanım oranlarının gün geçtikçe artmasını sağlamaktadır. Pandemi döneminde ise bireyler evde daha fazla vakit geçirmeye başlamıştır. Evde kalınan süre içerisinde de internet ve sosyal medya kullanımı artış göstermiştir.

Çalışmanın ilk tematik kategorisinde salgın döneminde değişen internet ve sosyal medya kullanım alışkanlıkları değerlendirilmiştir. Katılımcıların hepsi, bu dönemde internet ve sosyal medyayı daha fazla kullandıklarını ifade ederken; bu durumun olumlu ve olumsuz sonuçları olduğunu belirten katılımcılar olmuştur. Bilgiye erişim konusunda olumlu bir bakış açısı ortaya çıkarken; boş zamanların tamamıyla internet ve sosyal medya tarafindan ele geçirilmesi de olumsuz bir bakış açısı olarak kendini göstermiştir. Sosyal izolasyon ve gönüllü karantina döneminde özellikle gündemi takip etmek için sosyal medya kullanımı artmıştır. Salgın öncesinde sosyal medyayı iletişim ve başka işlevleri için kullanan katılımcıların salgın döneminde gündemi takip etmek için sosyal medyaya yöneldiği görülmüştür. Bu durumun nedenlerinden biri de salgın döneminde sağlık bakanının ve diğer yetkili kişilerin özellikle twitterı bilgi aktarımı için kullanmaları olarak gösterilebilir.

Çalışmanın ikinci tematik kategorisi birinci tematik kategoriyi tamamlar niteliktedir. İkinci kategoride, sosyal izolasyon ve gönüllü karantina döneminde internetin ve sosyal medyanın kullanım amaçlarının neler olduğu ortaya çıkarılmaya çalışılmıştır. Bu bölümde, araştırmaya katılan katılımcıların benzer cevaplar verdikleri görülmüştür. Katılımcılar; gündemi daha hızlı takip etmek, sosyal medya üzerinden canlı yayınlar yapmak, dijital olarak erişime açılan kültürel faaliyetlere katılmak, iletişim kurmak ve film, dizi izlemek için internet ve sosyal medyayı kullandıklarını ifade etmişlerdir.

Çalışmanın üçüncü tematik kategorisi sosyal izolasyon ve gönüllü karantina döneminde, internet ve sosyal medyanın hayatımıza ne gibi katkılar yaptığı üzerine şekillenmiştir. Ücretsiz şekilde erişime açılan kültürel faaliyetlerin olumlu bir katkı yaptığı fikri ön plana çıkmıştır. Ücretsiz konserler, müze gezileri bunlara örnek olarak verilmiştir. Bir diğer kazanım ise, bazı kurumların ücretsiz olarak erişime açtığı kaynaklar olarak gösterilmiştir. Uzaktan eğitim sürecinde bu kaynakların önemli olduğu vurgulanmıştır. Bu bölümde, sosyal izolasyon ve gönüllü karantina döneminde, internet ve sosyal medyanın bazı olumsuzluklara da neden olduğu üzerinde durulmuştur. Özellikle sadece dikkat çekmek, popüler olmak ve beğeni almak adına yapılan paylaşımlar buna örnek olarak verilmiştir. Bunun yanında insanların eğlence içeriklerine daha fazla rağbet etmesinin de internetten yararlanmayı olumsuz etkilediği üzerinde durulmuştur. 
Çalışmanın son kategorisinde, katılımcıların hangi tür dijital içerikleri takip ettikleri ve dijital içerik üretip üretmedikleri sorularına yanıt aranmıştır. Katılımcılar bu dönemde özellikle ilgi alanlarına yönelik içerikleri takip ettiklerini ifade etmişlerdir. Bunun yanında katılımcıların farklı alanlarda içerik ürettikleri görülmüştür. Edebiyat, canlı yayın, fotoğraf, haber ve eğitim bunlara örnek olarak verilebilir. Ayrıca, henüz dijital içerik üretiminde bulunmayan; ama bunun hazırlığı içinde olan katılımcılar da mevcuttur. Dijital içeriklerin üretim sebebi ise beğeni almak, kendini sosyal medya üzerinden var etmek ve diğer insanlara fayda sağlamak olarak belirtilmiştir.

Özetle, enformasyon toplumunda internet ve sosyal medya, etkisini ve kullanım alanlarını arttırmıştır. Özellikle pandemi döneminde, internet ve sosyal medya kullanım oranlarında artış olduğu ortaya çıkmıştır. Bireysel yaşam tarzının da ön plana çıkması, evde kal kampanyaları ve alınan önlemler internet ve sosyal medya kullanımını doğrudan etkilemiştir. İnternetin ve sosyal medyanın olumlu özellikleri olduğu gibi olumsuz özellikleri de vardır. İnternet ve sosyal medya kullanımının arttığ 1 bu dönemde yeni medya okuryazarlığının doğru şekilde yapılması, internetteki dezenformasyona dikkat edilmesi ve boş zamanların tamamıyla teknoloji aracılığıyla sürdürülmemesi gerekmektedir. Bu çalışma, bu alanda mikro bir bakış açısı sunmaya çalışmıştır. Bundan sonra alanla ilgili makro düzeyde çalışmaların gerçekleştirilmesi daha geniş bir bakış açısıyla konuya yaklaşılmasına yardımcı olacaktır.

\section{Kaynakça}

Altay, D. (2005). “McLuhan” Kadife Karanlık 21. Yüzyıl İletişim Çağını Aydınlatan Kuramcılar (Haz: N.Rigel, G. Batuş, G. Yücedoğan ve B.Çoban). İstanbul: Su Yayınevi.

Baldini, M. (2000). İletişim Tarihi. G. Batuş (çev.). İstanbul: Avcıl Basım Yayın.

Baudrillard, J. (2012). Tüketim Toplumu Söylenceleri / Yapıları. H. Deliceçaylı ve F. Keskin (çev.). İstanbul: Ayrıntı Yayınları.

Baudrillard, J. (2018). Simülakrlar ve Simülasyon. O. Adanır (çev.). Ankara: Doğu Batı Yayınları.

Binark, M. ve Bayraktutan, G. (2013). Ayın Karanlı Yüzü: Yeni Medya ve Etik. Istanbul: Kalkedon Yayınları.

Bourse, M. ve Yücel, H. (2012). İletişim Bilimlerinin Serüveni. İstanbul: Ayrıntı

Yayınlar1.

Braun, V. and Clarke, V. (2006). Using Thematic Analysis in Psychology, Qualitative Research in Psychology, Sayı: 3, Cilt: 2, s.77-101.

Çakır, M. (2014). "Yeni Medyaya İlişkin Eleştirel Yaklaşımları ve Tespitleri ile Christian Fuchs" Yeni Medyaya Eleştirel Yaklaşımlar. (Ed: M. Çakır). İstanbul: Doğu Kitabevi. 
Çakır, M. (2015). Internette Gösteri ve Gözetim Eleştirel Bir Okuma. Ankara: Ütopya Yayınevi.

Eldeniz, L. (2010). “İkinci Medya Çağında Etkileşimin Rolü ve Web 2.0” İkinci Medya Çağında İnternet. (Der: F. Aydoğan ve A. Akyüz). İstanbul: Alfa Basım Yayım Dağıtım. 18-35.

Fereday, J. M. and Cochrane, E. (2006). Demonstrating Rigor Using Thematic Analysis: A Hybrid Approach of Inductive and Deductive Coding and Theme Development, International Journal of Qualitative Methods, Say1: 5, Cilt: 1, s. 1-11.

Fuchs, C. (2017). "Google Kapitalizmi” (Çev: Ç. Çavuşoğlu). Yeni Medya Kuramcılarından Yeni Medya Kuramları. (Ed: F. Aydoğan). İstanbul: Der Yayınları. 7185.

Güngör, N. (2018). Illetişim Kuramlar ve Yaklaşımlar. Ankara: Siyasal Kitabevi.

Kalaman, S. (2019). Yeni Medya ve Dijital Gözetim: Türkiye'deki Sosyal Medya Kullanıcıları Üzerine Bir Araştırma. 26:2, Yönetim ve Ekonomi. 575- 594.

Kar, A. ve Güven. K, S, (2016). "Medya, Teknoloji, Şiddet ve Haz Sarmalı" Metin Çözümlemeleri. (Der: Y. ve N. Çokmak). İstanbul: Ayrıntı Yayınları.

Karataş, Ş. ve Binark, M. (2016). Yeni Medyada Yaratıcı Kültür: Troller ve Ürünleri 'Caps'ler. 1:2. TRTakademi.

Lyons, A. and Rohleder, P. (2015). Qualitative Research in Clinical and Health Psychology, United Kingdom: Palgrave Macmillan.

Marks, D. F. and Yardley, L. (2004). Research Methods for Clinical and Health Psychology, London: Sage.

Mattelart, A. ve Mattelart, M. (2017). İletişim Kuramları Tarihi. M. Zıllıŏglu (çev.). İstanbul: İletişim Yayınları.

OECD (2001), “Understanding the Digital Divide”, OECD Digital Economy Papers, No. 49, OECD Publishing, Paris. http://dx.doi.org/10.1787/236405667766 (Erişim tarihi: 9.07.2020).

Özçetin, B. (2018). Kitle İletişim Kuramları Kavramlar, Okullar, Modeller. İstanbul: İletişim Yayınları.

Öztürk, L. (2005). Türkiye'de Dijital Eşitsizlik: TÜBİTAK- BİLTEN Anketleri Üzerine Bir Değerlendirme. 24. Erciyes Üniversitesi İktisadi ve İdari Bilimler Fakültesi Dergisi. 111-131.

Saldana, J. (2009). The Coding Manual for Qualitative Researchers, London: Sage.

Stevenson, N. (2008). Medya Kültürleri Sosyal Teori ve Kitle İletişimi. G. Orhon ve B. E. Aksoy (çev.). Ankara: Ütopya Yayınevi. 
Taylor, S. J. and Bogdan, R. C. (1989) Introduction to Qualitative Research Methods: The Search for Meanings, New York: John Wiley \& Sons.

Toffler, A. (2008). Üçüncü Dalga Bir Fütürist Ekonomi Analizi Klasiği. S. Yeniçeri (çev.). İstanbul: Koridor Yayıncılık.

Tokgöz, O. (2012). Temel Gazetecilik. Ankara: İmge Kitabevi.

Tokgöz, O. (2015). Illetişim Kuramlarına Anlam Vermek Başlangıcından Günümüze Anglo- Amerikan İletişim Kuramı. Ankara: İmge Kitabevi.

Uzun, R. (2013). “Teknoloji Merkezli Yaklaşımlar.” İletişim Kuramları. (Ed: E. Yüksel). Eskişehir: Anadolu Üniversitesi Yayınları. 107- 132.

Yıldırım, O. (2019). Kültür Endüstrisi Olarak İnternetin Bireysel Özgürleşme ve Toplumsal Dayanışma Kavramları Çerçevesinde İncelenmesi. Yayımlanmamış Doktora Tezi. Eskişehir: Anadolu Üniversitesi Sosyal Bilimler Enstitüsü.

\section{Internet Kaynaklart}

Morozov, E. (2011). "Facebook and Twitter are just places revolutionaries go", https://www.theguardian.com/commentisfree/2011/mar/07/facebook-twitterrevolutionaries-cyber-utopians (Erişim tarihi: 9.07.2020).

TDK Sözlüğü (2020). "Dezenformasyon.” https://sozluk.gov.tr/ (Erişim Tarihi: 10.07. 2020).

TDK Sözlüğü (2020). “Karantina.” https://sozluk.gov.tr/ (Erişim Tarihi:10. 07.2020).

Medyascope.tv (2020). "Koronavirüs Zaman Çizelgesi: Ne Zaman Ortaya Çıktı? Nas1l Yayıldı? Önemli Tarihler Nelerdi? https://medyascope.tv/2020/04/05/koronaviruszaman-cizelgesi-ne-zaman-ortaya-cikti-nasil-yayildi-onemli-tarihler-nelerdi/, (Erişim Tarihi: 9.04.2020).

TRThaber.com (2020). “Türkiye'de İlk Koronavirüs Vakası Tespit Edildi." https://www.trthaber.com/haber/gundem/turkiyede-ilk-koronavirus-vakasi-tespitedildi-466216.html (Erişim Tarihi: 9.04.2020).

Onedio.com (2020) “Türkiye'nin Koronavirüsle Mücadelede Son Bir Haftada Aldığı Önlemler” https://onedio.com/haber/turkiye-nin-koronavirusle-mucadelede-son1-haftada-aldigi-onlemler-900532 (Erişim tarihi: 9.04.2020).

Medicakpark.com (2020). "Kolera nedir?" https://www.medicalpark.com.tr/ kolera-nedir/hg 1850\#: :text=Do\%C4\%9Fal\%20afetlerden\%20etkilenen $\% 20 \mathrm{ve} \% 20$ sava $\%$ C5\%9Fan,ad\%C4\%B1\%20verilen\%20bir\%20zehir\%20\%C3\%BCretir. (Erișim tarihi: 9.07.2020). 
Bbc.com (2020). "İspanyol Gribi: 50 Milyon İnsanı Öldüren Salgın Bittiğinde Dünya Ne Haldeydi?" https://www.bbc.com/turkce/haberler-dunya-52473039 (Erişim tarihi: 9.07.2020).

Ntv.com.tr (2020). "1968 Hong Kong Gribi ve Ardından H1N1” https:/www.ntv. com.tr/saglik/1968-hong-kong-gribi-ve-ardindan-h1n1,Fh3E_Zja10eLHXXk8eRZRQ (Erişim tarihi: 9.07.2020).

https://www.medicalpark.com.tr/ebola-virusu-nedir-belirtileri-ve-tedaviyontemleri-nelerdir/hg-1336 (Erişim tarihi: 9.07.2020).

Medicalpark.com (2020). "Ebola Virüsü Nedir? Belirtileri ve Tedavi Yöntemleri Nelerdir?" https:/www.medicalpark.com.tr/ebola-virusu-nedir-belirtileri-ve-tedaviyontemleri-nelerdir/hg-1336 (Erişim tarihi: 9.07.2020).

Bilheal.Bilkent.edu.tr (2020). "Sars Nedir?" http://bilheal.bilkent.edu.tr/aykonu/ Ay2003/may03/sarsturk.htm (Erişim tarihi: 9.07.2020)

Medicalpark.com (2020). "Domuz Gribi Nedir? Domuz Gribi Belirtileri Nelerdir?" https://www.medicalpark.com.tr/domuz-gribi/hg-1966 (Erişim tarihi: 9.07.2020).

Euronews.com (2020). “Sağlık Bakanı Koca: Türkiye'de İk Koronavirüs Vakası Tespit Edildi." https://tr.euronews.com/2020/03/10/sagl-k-bakan-koca-koronaviruscovid-19-salg-n-ile-ilgili-ac-klama-yap-yor (Erişim tarihi: 9.07.2020).

Hürriyet.com.tr (2020). "Sosyal İzolasyon Nedir? İzeole Etmek Ne Demek? https:// www.hurriyet.com.tr/galeri-sosyal-izolasyon-nedir-izole-etmek-ne-demek-41491437/2 (Erişim tarihi: 10.07.2020).

Bbc.com (2020). "Koronavirüs: Sosyal mesafe ve kendini izole etmek ne demek? https://www.bbc.com/turkce/haberler-dunya-52012336 (Erişim tarihi: 10.07.2020).

Açıkerişim.Gelişim.edu.tr (2020). "Pandemi ve Psikolojik Etkileri." http:// acikerisim.gelisim.edu.tr/xmlui/bitstream/handle/11363/2202/Pandemi\%20ve\%20 Psikolojik\%20Etkileri.pdf?sequence=1\&isAllowed=y, 2020) (Erişim tarihi: 10.07.2020).

Hürriyet.com (2020). “Koronavirüs Salgını İnternet Trafiğini Nasıl Etkiliyor? https://www.hurriyet.com.tr/teknoloji/koronavirus-salgini-internet-trafigini-nasiletkiliyor-41478132. (Erişim tarihi: 11.07.2020).

Habertürk.com (2020). "Koronavirüs İnterneti Nasıl Etkiledi? Türk Telekom Online Toplant1 ile Son Durumu Paylaştı." https://www.haberturk.com/turkiye-nininternet-kullanimi-koronavirus-ile-yuzde-50-artti-haberler-2623692-teknoloji (Erişim tarihi: 11.07.2020).

Made for Minds (2020). "Netflix'in Abone Sayıs1 183 Milyona Çıktı." https://www.dw.com/tr/netflixin-abone-say\%C4\%B 1s\%C4\%B 1-183-milyona\%C3\%A7\%C4\%B1kt\%C4\%B1/a-53206573 (Erişim tarihi: 13.07.2020). 
Webrazzi.com (2020). “Covid-19 Salgınında Ünlüler Sosyal Medya Üzerinden Ev Konserlerine ve Kitap Okuma Etkinliklerine Başladı.” https://webrazzi.com/2020/03/18/ covid-19-salgininda-unluler-sosyal-medya-uzerinden-ev-konserlerine-ve-kitap-okumaetkinliklerine-basladi/ (Erişim tarihi: 13.07.2020).

Trthaber.com(2020). “Evde İnternetKullanımında KoronavirüsArtışı.”https://www. trthaber.com/haber/gundem/evde-internet-kullaniminda-koronavirus-artisi-468354.html (Erişim tarihi: 14.07.2020).

Wearesocial.com, (2020). https://wearesocial.com/digital-2020 (Erişim Tarihi: 10.07.2020). 